\title{
PRODUKTU DEMONSTRAVIMO VAIDYBINIUOSE FILMUOSE YPATUMAI (TEORINIS ASPEKTAS)
}

\author{
Lina Pilelienè, Sigita Jurgilaitė \\ Vytauto Didžiojo universitetas, Lietuva
}

\begin{abstract}
ANOTACIJA
Straipsnyje analizuojami produktų demonstravimo vaidybiniuose filmuose ypatumai. Ši rẻmimo priemonè, vis dažniau naudojama kino praktikoje, sulaukia vis daugiau filmų kūrèjų ar rèmëju susidomejjimo, šị reiškini èmè nagrinèti ir mokslo tyrèjai. Straipsnyje nagrinèjama problema, kaip demonstruoti produktus vaidybiniuose filmuose. Norint atskleisti produktu demonstravimo samprata, pateikiami šios rèmimo veiklos principai, funkcijos, sąlygos, motyvai ir būdai.
\end{abstract}

Raktažodžiai: pardavimų skatinimas, reklama, rẻmimo priemonès.

\section{IVADAS}

Produktų demonstravimas filmuose naudojamas skleidžiant produkto žinomumą, kuriant teigiamas produkto asociacijas ar norint padidinti jo pardavimus (Karrh et al., 2001). Ši rèmimo priemonè sulaukia ne tik filmų kūrẻjų ar rẻmëju susidomejjimo, ją pradejjo nagrinèti ir mokslo tyrèjai. Nuo pirmo produktų demonstravimo atvejo, kuris užfiksuotas 1896 metais filme „Washing Day in Switzerland“, buvo tiriama, kaip žiūrovai reaguoja ị produkto demonstravimą, kaip ji priima, kaip tai veikia paties produkto issiminimą, ar ši rèmimo priemonė veikia pirkimų ketinimus, taip pat buvo vertinami produktų demonstravimo kultūriniai ypatumai.

Produktu demonstravimas filmuose tapo ne tik svarbia rèmimo priemone, bet veikia ir visuomenę. Daugelis filmu gali daryti įtaką žiūrovams, paveikti jų socialines nuostatas, formuoti tos priemonès pirkimo ipročius (Karrh et al., 2001).

Nors ši rèmimo priemonè plačiai naudojama, nepavyko rasti Lietuvos autorių mokslinių publikacijų, kurios analizuotų produktų demonstravimą lietuviškuose filmuose. Lietuvoje pramoginio pobūdžio filmų pastatoma vis daugiau. Tai puiki terpé produktams demonstruoti. Žiūrint mūsų šalyje pastatytus filmus jau galima užfiksuoti šios rèmimo priemonès praktinius panaudojimo atvejus. Taigi aktualu nagrinėti produktų demonstravimo filmuose ypatumus.

Nagrinėjama problema: kaip demonstruoti produktus vaidybiniuose filmuose? Užsienio autoriai tiria produktų demonstravimą filmuose įvairiais aspektais (nagrinejjama itaka žiūrovų pirkimo ketinimams, šios priemonès paveikumas žiūrovų issiminimui, produkto žinomumo didinimas, bendras šios priemonès vertinimas ir pan.). Lietuvoje produktų demonstravimas vaidybiniuose filmuose neanalizuotas.

Tyrimo objektas - produktų demonstravimo vaidybiniuose filmuose.

Tikslas - atskleisti produktų demonstravimo vaidybiniuose filmuose ypatumus. 


\section{METODIKA}

Pagrindiniai produktų demonstravimo filmuose ypatumai atskleidžiami atliekant mokslinès literatūros kokybinę turinio analizę. Atsižvelgiant ị tai, kad Lietuvos autorių ižžvalgų nagrinėjama tematika rasti nepavyko, pasirinkta analizuoti užsienio autorių (Sargent ir kt., 2001; Jin, Villegas, 2007; Sung ir kt., 2008; Wiles, Danielova, 2009 ir kt.) atliktus tyrimus. Straipsnyje siekta atskleisti skirtingu autorių požiūrị i produktų demonstravimą vaidybiniuose filmuose, apibendrinti pateikiamus apibrèžimus ir galimas analizuojamos rẻmimo veiklos taikymo sritis. Teoriniam tyrimui atlikti naudoti bendrieji mokslinio tyrimo metodai - mokslinès literatūros loginè analizė, sintezè.

\section{TYRIMO REZULTATAI IR JŲ APTARIMAS}

Produkto demonstravimo filmuose samprata. Dinamiškai augantis vartotojų pasipriešinimas tradicinèms rinkodaros priemonėms (jau prieš kelis dešimtmečius susirūpinta tuo, kad žiūrovai kontroliuoja reklamų žiūrẻjimą arba tiesiog perjungia kanalą reklamos metu) organizacijas privertė ieškoti alternatyvių kelių norint pasiekti tikslinę auditoriją ir parodyti savo produkto privalumus (Keller, 2001). Vienu iš alternatyvių kelių tapo produkto demonstravimas filmuose.

Produkto demonstravimas - tai suplanuotas produkto, kuris gali daryti itaką vartotoju nuomonès formavimui arba jų pirkimo ketinimams, pateikimas filmuose arba televizijos programose. Tai konkrečių prekès ženklų ar jų identifikavimo ittraukimas i visuomenès informavimo priemones panaudojant garsinius ar vizualius elementus (Balasubramanian, 1994). Pagrindinis tokios komunikacijos priemonès tikslas - padidinti klientų isisąmoninimą ir daryti teigiamą itaką klientų pirmenybès teikimui ir apsisprendimui pirkti. Pirmieji prekių ženklų demonstravimo televizijos programose studijas atliko ir publikavo I. D. Nebenzahl ir E. Secunda (1993).

Produkto demonstravimo vaidybiniuose filmuose aspektai. Produkto demonstravimas vaidybiniuose filmuose, kaip ir kitos rinkodaros komunikacijos priemonès, tam tikru būdu veikia tikslinę auditoriją. E. Johnstone ir C. A. Dodd (2000) įvardija du produkto demonstravimo vaidybiniuose filmuose poveikio vartotojų elgsenai principus.

1. Salyginis mokymasis, kai mokomasi iš asociacijų tarp stimulo ir atsako. Šis mokymasis gali pasireikšti automatiniu atsaku i stimulus, kurie dažniausiai šio atsako nesukeltų. Toks mokymasis veikia kaip principas, kada pasekmès vertinamos pagal ankstesnius veiksmus ar atsakus. Pagal ši principą produkto demonstravimas yra stimulas, kuriuo siekiamas tikslas - vartotojų noro nedelsiant pirkti sužadinimas.

2. Mokymasis stebint. Jis nusako, kaip produkto demonstravimas veikia auditorija, kai individas stebi kitų elgesi. Mokymasis stebint - tai tokia elgsena, kai auditorija kopijuoja ekrane matomą elgesi ir su juo susijusias galimas pasekmes. Taigi norint, kad žiūrovas susidarytų ispūdị apie produktą, jam nebūtina pačiam išgyventi su pačiu prekès ženklu susijusių nusivylimu ar pasitenkinimu - vartotojui užtenka pamatyti ekrane tai darant aktorių. Šio matymo užtenka, kad būtų sukurtas motyvas pirkti. Lygiai tuo pačiu būdu sukuriamas neigiamas požiūris i produktą, kai filmuose jị naudoja socialiai nepriimtinas veikejjas. 
Produkto demonstravimas filmuose gali atlikti kelias funkcijas. Jos gali būti tokios:

- Asociaciju kūrimas. M. A. Wiles ir A. Danielova (2009) teigia, kad pirminis produkto demonstravimo tikslas turètų būti ne padidinti produkto žinomumą, bet sustiprinti prekinių ženklų asociacijas. Pavyzdžiui, Mercedes savo automobilius demonstravo filme „Vyrai juodais drabužiais 2“ (Men in Black II), sukuriant ispūdi, kad Mercedes vairavimas susijęs su smagumu - taip apeliuojama i jaunesnę auditoriją. Asociacijų kūrimas - vienas iš mokymosi būdų, kai auditorija, stebėdama tai, kas vyksta ekrane, susidaro ịspūdi, kad matomas emocijas jie gali patirti realiame gyvenime.

- Žinomumo didinimas. R. J. Avery ir R. Ferraro (2000) nurode, kad prekių ženklai filmuose vartotojų dèmesi patraukia lygiai taip pat, kaip ir reklamose. Daugelio tyrimų rezultatai parodè, kad produkto pateikimas filmuose veiksmingai didina prekių ženklų ar prekių isisąmoninimą (Gupta, Lord, 1998; Karrh, 1998). Produkto demonstravimas filmuose gali paveikti prekès ženklo atpažinimą, atsaką jam, požiūrị ir bendrai demonstravimo priimtinumą. S. J. Gould ir kt. (2000) nustatė, kad produkto demonstravimas gali paveikti prekès ženklo atpažistamumą, atgaminimą ir požiūrị i ji. Pavyzdžiui, Holivudo filmų pramonès praktikoje kuriami filmai dažnai rodomi ir kitose šalyse, ir taigi tai tampa puikia priemone, didinančia prekès ženklo žinomumą pasauliniu mastu.

- Teigiamo i̇vaizdžio stiprinimas. Kiekviena organizacija siekia, kad jos produktas ar prekès ženklas būtų pateikiamas skatinant teigiamas asociacijas. Lèktuvus gaminančios bendrovès niekada neafišuos savo prekès ženklo filmuose apie lèktuvų katastrofas, cigarečių kompanijos nerodys savo produkto filmuose, kuriuose personažai nuo rūkymo suserga věžiu. Produkto demonstravimas padeda gerinti produkto įvaizdi, kuriamą kitomis marketingo priemonėmis.

Y. Sung ir kt. (2008) teigimu, dažniausiai prekių ženklams demonstruoti pasirenkamos komedijos ir veiksmo filmai. Populiariausios prekių kategorijos filmuose yra nealkoholinių ir alkoholinių gėrimu, automobilių, drabužių ir maisto prekių ženklai. Nepriklausomai nuo filmo žanro ar reklamuojamo produkto kategorijos, visais atvejais produktas filme turi būti demonstruojamas laikantis tam tikrų sąlygų, jeigu norima susilaukti didžiausio paveikumo. Norint kad produkto demonstravimas būtų veiksmingas, jis turi atitikti šias sąlygas:

- Natūralumo. Norint nesukelti žiūrovų pasipiktinimo dèl prekių ženklų demonstravimo filmuose, būtina gerai apsvarstyti filmo siužetą ir jo ryši su prekès ženklu. Prekiu ženklai ir produktai filmo scenose turi būti pateikiami natūraliai. Tinkamas ir laiku demonstruojamas produktas sustiprina reklamos poveikị, toki kaip prekès ženklo atpažinimas (Karrh, 1998) ir, atvirkščiai, jei produkto demonstravimas suvokiamas kaip trukdantis ar nutraukiantis istorijos ar scenos tęstinumą filme, jis sukelia didelį auditorijos nepasitenkinimą (Sung ir kt., 2008).

- Prekés ženklo ir auditorijos atitikimas. Analizuojant Holivudo praktiką pastebima, kad žmonès dažniausiai peržiūri scenarijus ir nurodo, ir kaip pateikti prekès ženklą, kad auditorija būtu pasiekta. Dažniausiai pasirenkami tie filmai, kurių auditorija atitinka ir prekès ženklo tikslinę grupę. Kai kurios organizacijos netgi kontroliuoja produktų demonstravimą filmuose. Pavyzdžiui, JAV ¿monè „Caterpillar“, gaminanti statybos įrenginius, aktyviai naudoja legalius būdus ir stabdo filmu kūrejjus demonstruoti jos produktus su neigiamu atspalviu (Gupta ir kt., 2000). 
Kiekviena organizacija, priklausomai nuo esamos situacijos ir siekiamų tikslų, naudoja produktų demonstravimą filmuose turèdama tam tikrų motyvų. Pagrindiniai motyvai:

- Realistiškumo siekimas. J. A. Karrh (1998) nurodè, kad žmonès apdoroja informaciją apie filmų personažus lygiai tokiu pat būdu, kaip ir kasdieniame savo gyvenime. Kaip teigia M. R. Solomon ir B. G. Englis (1994), šis realistiškumo efektas yra viena veiksmingiausių rinkodaros technikų. Realistiškumo poveikis sustiprëja tuose filmuose, kuriuose rodomas kasdienis gyvenimas, todèl vartotojas dažnai ir pasirenka juos. Filmuose ar atskirose scenose realistiškumas kuriamas naudojant populiarias kultūrines priemones, tokias kaip reklama, viešieji ryšiai, reklaminiai filmai ir realių produktų demonstravimas. Šiandienos vartotojas yra labiau linkęs visuomenès informavimo priemones vertinti kaip tikrovès pavaizdavimą, kuri yra kasdienio gyvenimo natūrali dalis, nors ši „realybė“ kuriama rinkodaros specialistu (Sung et al., 2008). Taigi produktą demonstruojant filmuose galima pasakyti daug daugiau nei reklamose.

- Mažas reguliavimas. Produkto demonstravimas filmuose nèra reguliuojamas ir dažniausiai priklauso nuo sumokamos sumos, kuri priklauso nuo produkto rodymo trukmès, reikšmingumo ir interakcijos su personažais. Ši priemonè labai naudinga organizacijoms, kuriu galimybė reklamuotis apribota kitais būdais, pavyzdžiui, tabako ir alkoholio gaminiu gamintojams, kuriems reklama televizijos programose yra ribota.

- Komunikavimo kanalu perpildymas. Pastaraisiais metais labai išaugo rinkodaros kanalų galimybès. Skaitmeninė televizija, internetas, augantis komercinių radijo stočių skaičius padidino tokių kanalų pasirinkimą, tačiau kartu iškèlè didesnius reikalavimus komunikavimo su galimais klientais veiksmingumą. Kuo daugiau triukšmo reklaminès žinutės skleidimo metu, tuo mažesnè tikimybè, kad ji bus išgirsta. Produkto demonstravimas filmuose padeda šio triukšmo išvengti.

- Filmo kūrèju palankūs siūlymai. Realistiškumo kūrimas svarbus ne tik produktú gamintojams, kaip buvo išskirta anksčiau, bet ir patiems filmo kūrejjams. Norèdami sukurti realistiškai atrodanti filmo pasauli, kūrẻjai nevengia naudoti tikrų prekių ženklų. Šiuo atveju organizacijos gali gauti siūlymų iš pačių filmų kūrèjų.

Produkto demonstravimo filmuose būdai. Kiekviena įmonè, nusprendusi savo produkciją demonstruoti filmuose, turi apgalvoti, kaip produktas ar prekès ženklas bus pateiktas, kad būtų pasiektas didžiausias poveikis. Filmuose prekių ženklai gali būti pateikiami keliais būdais.

P. B. Gupta ir K. R. Lord (1998) siūlo dviejų dimensijų produkto demonstravimo kategorizavimą (toki skirstymą pateikia ir E. Johnstone ir C. A. Dodd, 2000): 1-a dimensija demonstravimo būdas (angl. mode) - jausmai aktyvuojami stimulų; kita - demonstravimo reikšmingumas (angl. prominence) - laipsnis, kuriuo produkto pateikimas apima duomenis, priverčiančius auditoriją sukoncentruoti dėmesi $\mathfrak{i}$ ji. Toliau autoriai pateikia tris produkto demonstravimo strategijas: tik vizualus, tik garsinis ir vizualus kartu su garsiniu. Pirmasis būdas, kai rodomas tik prekès ženklas, produktas ar kitas vizualus prekès ženklo identifikatoriai be jokios žodinès žinutės garso takelyje ar kitų garsinių priemonių, kurie patrauktų dėmesị. Antras būdas apima užsiminimą apie prekès ženklą ar veikèjo su prekès ženklu susijusios žinutès perteikimas garsu, nerodant produkto ekrane. Trečias būdas apima prekès ženklo ar produkto rodymą ir tuo pačiu kalbėjimą apie ji. 
Kiekvienas iš minètų būdų gali būti iškilus (akivaizdus) arba subtilus. Iškilus yra toks būdas, kai produktas akivaizdžiai matomas koreguojant jo dydị, poziciją ekrane ar centriškumą scenoje ir veiksmo metu. Subtilus pateikimas yra toks, kai prekès ženklas nėra rodomas akivaizdžiai (pvz., mažo dydžio, fone už pagrindinio kadro, pateikiamas su kitų produktų rinkiniu, komplektu, matomas tik trumpą laika). P. B. Gupta ir K. R. Lord (1998) nustaté, kad gerai matomas produkto demonstravimas yra geriau atpažistamas nei subtilus. Tai patvirtino ir A. D' Astous ir F. Chartier (2000), tyrimais irodę, kad akivaizdesnis produkto pateikimas lemia geresnị prekès ženklo isiminimą. Subtilų produkto pateikimą filmo kūrejjams lengviau pritaikyti ir panaudoti filmo scenose, jis gali būti įtrauktas net i scenos foną.

P. B. Gupta ir K. R. Lord (1998), pateikę produkto demonstravimo klasifikavimą, taip pat bandè nustatyti, kuris produkto demonstravimo būdas veiksmingesnis. Šie autoriai savo tyrimu nustatè, kad naudojant tik garsinę priemonę sulaukiama geresnio žiūrovų atpažinimo nei naudojant tik vizualią. Vien tik vizualus būdas yra naudojamas dažniausiai, tik su juo yra susijusi rizika, kad žiūrovai neatkreips dėmesio i produkta, demonstruojamą be garso.

C. La Ferle ir S. M. Edwards (2006) išskyrė du produkto demonstravimo filmuose būdus tai epizodinis prekès ženklo parodymas ir pokalbis, kurio metu filmo veikejjai diskutuoja apie ji. Tyrimas atskleidè, kad kalbèjimas apie prekès ženklą yra veiksmingesnè priemonè, ir jos dèka pastarasis lengviau i̇simenamas žiūrovų. Toks prekès ženklo pateikimas pasirodè artimesnis žiūrovams. Pasak autorių, pagrindinis produkto demonstravimo tikslas - supažindinti su nauju produktu ir parodyti jo panaudojimą. Tai susiję su realistiškumo kūrimu.

A. D'Astous ir F. Chartier (2000) siūlo produkto demonstravimą klasifikuoti pagal produkto ryši su scena, demonstravimo reikšmingumą ir santykị su filmo aktoriais. Jie nustatė, kad produkto demonstravimas veiksmingiausias tada, kai filmo žvaigždẻ komunikuoja su produktu, kai produktas pateikiamas akivaizdžiai ir kai jo demonstravimas susijęs su scena.

Norint kad produkto demonstravimas vaidybiniuose filmuose būtų veiksmingas, svarbu analizuoti prekès ženklo rodymo duomenis, paremtus prekių ženklų tipų dimensijomis, produkto rodymo ir paminèjimo laipsni, scenos vietą ir laiką, vizualu/verbalini reikšmingumą, veikèjo itraukimą, rodymo dažnumą ir ilgumą, padèti scenoje, charakterio ryškumą (svarbumą) ir demografines jo savybes. Produkto sąsajos su teigiamybėmis, tokiomis kaip žymūs žmonès, teigiamai veikia vartotoju reakciją ir produkto vertinimą. Tai savo tyrimais patvirtino ir A. D' Astous ir F. Chartier (2000).

E. Johnstone ir C. A. Dodd (2000) be visų jau anksčiau aprašytų demonstravimo būdų išskiria dar du - tiesiogini (pvz., Pepsi butelis ant virtuvès stalo) ir netiesiogini (pvz., stendai, matomi kadro fone). Šis produktų demonstravimo klasifikavimas labai panašus i jau minètą P. B. Gupta ir K. R. Lord (1998), kurie išskiria du demonstravimo pobūdžius - iškilu ir subtilu.

Pasirinktas būdas turi garantuoti produkto demonstravimo integralumą su pačiu filmu. Žiūrovai produkto pateikimą geriau įvertina tada, kai produktas natūraliai susijęs su scena ir filmo turiniu. Auditorija atidesnè tokioms scenoms, kuriose produktas labiau integruotas. Toks produkto pateikimas mažina jo atmetimo tikimybę. C. Stephens ir R. Molaro (2005) apibendrina, kad produkto demonstravimas apima vizualius, verbalinius, naudojimo (angl. hands on) ar siužeto aspektus. 
Apibendrinant mokslines įžvalgas galima teigti, kad produkto demonstravimas vaidybiniuose filmuose gali būti klasifikuojamas keliais kriterijais (žr. pav.).

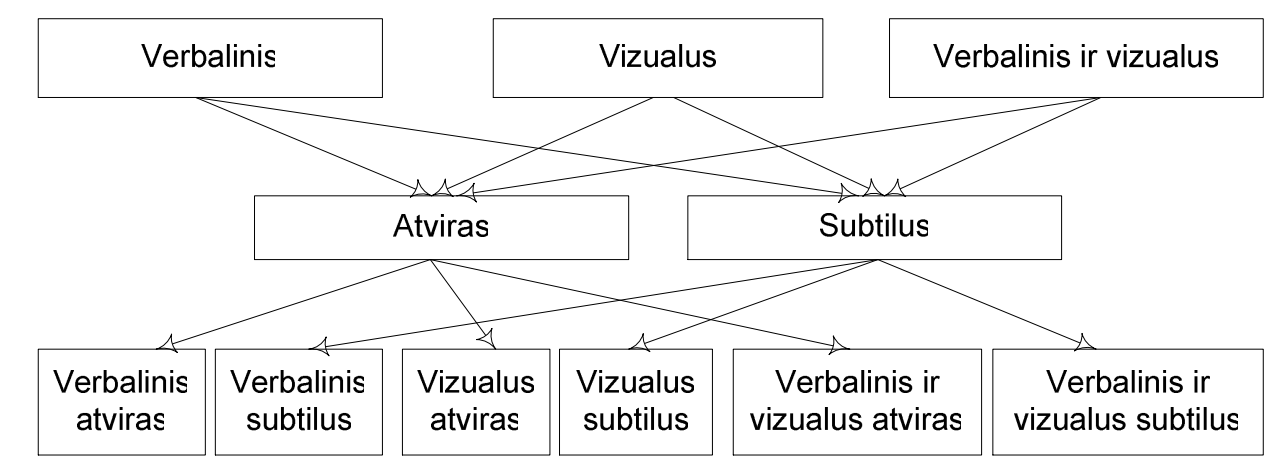

Pastaba. Sudaryta remiantis autorių analizuotais produkto demonstravimo skirstymo kriterijais.

Pav. Produkto demonstravimo filmuose klasifikavimas

Klasifikavimo pagrindą, pateiktą paveiksle, sudaro P. B. Gupta ir K. R. Lord (1998) siūlymai demonstravimą skirstyti ì verbalini, vizualu bei verbalinị ir vizualu kartu ir rinktis, kaip šios priemonès bus naudojamos - atvirai, ar subtiliai. Daroma prielaida, kad visus kitus elementus, kuriuos išskiria autoriai, apima šis pagrindinis skirstymas.

Nusprendus naudoti produkto demonstravimą filmuose, imonė pirmiausia turi rinktis, kokiu būdu naudosis. Kitas organizacijos spręstinas klausimas - kaip pasirinktas priemones naudoti. Priklausomai nuo situacijos ir produkto, galimi du sprendimo variantai: prekini ženklą ar produktą demonstruoti subtiliai ar akivaizdžiai. Priklausomai nuo pasirinkimo, toliau naudojami elementai kombinuojami. Apsisprendžiama, ar filmo personažas komunikuos su produktu ar ne, jei taip kokio svarbumo veikejjas bus pasirinktas (pagrindinis ar antraplanis), ką veikèjas su produktu darys (ji naudos ar apie ji kalbès, gal atliks abu veiksmus)? Nusprendžiama, kokią ekrano dali užims produktas, kurioje scenoje, kiek laiko, pirmame plane ar fone. Visos išvardytos detalès turi būti integruotos ir pateikiamos kuo natūraliau, siekiant geriausių rezultatų.

Atlikta analizė atskleidè, kad produkto demonstravimas vaidybiniuose filmuose yra veiksminga rèmimo priemoné, naudojama kino pramonèje. Lietuvoje taip pat yra kuriami filmai, taigi galima teigti, kad produktu demonstravimo vaidybiniuose filmuose integravimas i organizacijos rinkodaros planą gali lemti netgi organizacijos konkurencini pranašumą rinkoje.

\section{IŠVADOS IR PERSPEKTYVOS}

Nuolat augantis vartotoju pasipriešinimas tradicinėms rinkodaros priemonėms organizacijas privertė ieškoti naujų būdų, kaip pasiekti tikslinę auditoriją ir parodyti produkto privalumus. Vienas iš jų- produkto demonstravimas filmuose. Produkto demonstravimas yra produktų ar jų identifikavimo įtraukimas $\mathfrak{i}$ visuomenès informavimo priemones panaudojant garsinius ar vizualius elementus. Pagrindinis šios komunikacijos priemonès tikslas - padidinti vartotojų isisąmoninimą, daryti teigiamą itaką pirmenybei teikti ir apsisprendimui pirkti.

Pagrindiniai produktų demonstravimo filmuose privalumai yra natūralus produkto pateikimas, didelis vartotojų dėmesio koncentravimas, palankios finansinès sutartys, neišvengiamumas, personažo atskleidimas, teigiamų asociacijų kūrimas, pardavimų didinimas, tikslinès auditorijos pasiekimas. 
Atlikti tyrimai ir realūs užsienio organizacijų pavyzdžiai irodè, kad produktų demonstravimas vaidybiniuose filmuose padidina produkto žinomumą, sukuria teigiamą požiūrị i prekini ženklą ir taip tiesiogiai veikia pardavimų augimą.

Atliekant tolesnius produktu demonstravimo vaidybiniuose filmuose tyrimus tikslinga nustatyti ryši tarp demonstruojamo produkto kategorijos, vaidybinio filmo žanro ir demonstravimo veiksmingumo.

\section{LITERATŪRA}

1. Avery, R. J., Ferraro, R. (2000). Verisimilitude or Advertising? Brand Appearances on Prime-Time Television. The Journal of Consumer Affairs, 34 (2), 217-244.

2. Balasubramanian, S. K. (1994). Beyond advertising and publicity: Hybrid messages and public policy issues. Journal of Advertising, 23 (4), 29-46.

3. D'Astous, A., Chartier, F. (2000). A study of factors affecting consumer evaluations and memory of product placements in movies. Journal of Current Issues and Research in Advertising, 22, 31-40.

4. La Ferle, C., Edwards, S. M. (2006). Product placement, how brand appear on television. Journal of Advertising, 35 (4), 65-86.

5. Gould, S. J., Gupta, P. B., Grabner-Krauter, S. (2000). Product placements in movies: A cross-cultural analysis of Austrian, French and American consumers' attitudes toward this emerging, international promotional medium. Journal of Advertising, 29 (4), 41-59.

6. Gupta, P. B., Lord, K. R. (1998). Product placement in movies: The effect of prominence and mode on audience recall. Journal of Current Issues and Research in Advertising, 20 (1), 47-59.

7. Gupta, P. B., Balasubramanian, S. K., Klassen, M. L. (2000). viewers' evaluations of product placement in movies: Public policy issues and managerial implications. Journal of Current Issues and Research in Advertising, 22 (2), 41-52.

8. Jin, C., Villegas, J. (2007). The effect of the placement of the product in film: Consumers' emotional responses to humorous stimuli and prior brand evaluation. Journal of Targeting, Measurement and Analysis for Marketing, 15 (4), 244-255.

9. Johnstone, E., Dodd, Ch. A. (2000). Placements as mediators of brand salience within a UK cinema audience. Journal of Marketing Communications, 6, 141-158.

10. Karrh, J. A. (1998). Brand placement: A review. Journal of Current Issues and Research in Advertising, 20 (2), 31-49.

11. Karrh, J. A., Frith, K. T., Callison, C. (2001). Audience attitudes towards brand (Product) placement: Singapore and the United States. International Journal of Advertising, 20 (1), 3-24.

12. Keller, K. L. (2001). Mastering the marketing communications mix: Micro and macro perspectives on integrated marketing communication programs. Journal of Marketing Management, 17 (7), 819-847.

13. Nebenzahl, L. D., Secunda, E. (1993). Consumers' attitudes towards product placements in movies. International Journal of Advertising, 12, 1-11.

14. Sargent, J., Tickle J. J., Beach, M. et al. (2001). Brand appearances in contemporary cinema films and contribution of global marketing of cigarettes. The Lancet, 357, 29-32.

15. Solomon, M. R., Englis, B. G. (1994). The big picture: product complementarity and integrated communications. Journal of Advertising Reseach, 34, 57-63.

16. Stephens, C., Molaro, R. (2005). Product Screening. License, March [2012 01 15]. Prieiga internetu: http://www.koeppeldirect.com/images/Koeppel-article-April05.pdf

17. Sung, Y., Choi, J., Gregorio, F. (2008). Brand placements in Korean films, 1995-2003: A content analysis. Journal of International Consumer Marketing, 20 (3), 39-53.

18. Wiles, M. A., Danielova, A. (2009). The worth of product placement in successful films: An event study analysis. Journal of Marketing, 73 (4), 44-63. 


\title{
PECULIARITIES OF PRODUCT PLACEMENT IN MOVIES: THEORETICAL ASPECT
}

\author{
Lina Pilelienè, Sigita Jurgilaitè \\ Vytautas Magnus University, Lithuania
}

\begin{abstract}
Research background. According to J. A. Karrh et al. (2001) product placement in movies is used with intensions to extend product awareness, create positive associations with a product, or to promote sales. Product placement is becoming very successive tool of promotion; its impact on society is constantly growing. Many films can make an impact on society's attitudes, also, form buying patterns.

Despite a wide usage of this promotional tool, attempts to find scientific publications of Lithuanian authors considering this product placement in Lithuanian movies were unsuccessful. However, many cases of product placement can be observed in Lithuanian movies. Therefore, it becomes relevant to analyze the peculiarities of product placement in movies. The problem solved in the article is how to make product placement in movies. Foreign authors are constantly providing research on multiple aspects of product placement (its impact on viewers' purchase intentions, impact on memorization, product awareness, etc.); therefore, the lack of Lithuanian researches in the field substantiates the problem.
\end{abstract}

The object of the article is the peculiarities of product placement in movies.

The aim of the article is to reveal the peculiarities of product placement in movies.

Research method. Qualitative content analysis of scientific literature was provided to reveal the principal aspects of product placement in movies. Whereas there is a lack of Lithuanian authors' insights in the field, researches provided by foreign authors (Sargent et al., 2001; Jin, Villegas, 2007; Sung et al., 2008; Wiles, Danielova, 2009 et al.) were analyzed. Various approaches to product placement in movies provided by different authors are reviewed, different conceptions of product placement in the movies are generalized, and potential usage areas of the activity are revealed in the article. General scientific research methods of logical analysis and synthesis of scientific literature are applied for theoretical research.

Findings. Product placement in movies can be named as an alternative way to reach target audience and highlight product's advantages. Product placement is product's or its identifier's inclusion into media using sonic or visual elements. The main goal of product placement is to increase customer awareness, make positive impact on their preferences and purchase intentions.

Main advantages of product placement in the movies are naturalness, high concentration of viewer's attention, inevitability, and revelation of character, creation of positive associations, sales promotion, and the reach of target audience.

Scientific researches and real practices of foreign organizations have proven that product placement in the movies enhance product awareness, creates and increases positive impact on a brand. Accordingly, the direct impact on increase in sales can be observed.

Keywords: advertising, promotional tools, sales promotion. 


\title{
ОСОБЕННОСТИ ДЕМОНСТРИРОВАНИЯ ПРОДУКТОВ В ХУДОЖЕСТВЕННЫХ ФИЛЬМАХ: ТЕОРЕТИЧЕСКИЙ АСПЕКТ
}

\author{
Лина Пилелене, Сигита Юргилайте \\ Университет Витаутаса Великого, Литва
}

\section{РЕЗЮМЕ}

Теоретическое обоснование. По словам D. А. Karrh и др. (2001), демонстрирование продуктов (англ. product placement) в кино используется с целью расширить известность продукта, создать положительные ассоциации с продуктами или увеличить их продажу. Продукт-плейсмент становится очень последовательным инструментом продвижения, его влияние на общественность постоянно растёт. Многие фильмы могут повлиять на отношение общественности, создавая покупательское поведение.

Несмотря на широкое использование такого рекламного инструмента, попытки найти научные публикации литовских авторов о продукт-плейсмент в кино были неудачными. Однако в литовских художественных фильмах можно обнаружить много случаев демонстрирования продуктов. Поэтому особенности демонстрирования продуктов в фильмах становится актуальной темой и подлежит подробному анализу. В статье рассматривается проблема, как осуществлять продукт-плейсмент в художественных фильмах. Иностранными авторами постоянно ведутся исследования по нескольким аспектам демонстрирования продукта (его влияние на намерения зрителей как покупателей, влияние на запоминание, осведомление о товаре и т. д.). Можно сказать, что отсутствие исследований литовских авторов о демонстрировании продуктов в литовских художественных фильмах указывает на существовании научной проблемы.

Объектом статьи являются особенности демонстрирования продуктов в художественных фильмах.

Цель статьи - установить особенности демонстрирования продуктов в художественных фильмах.

Методика. С целью выявить основные аспекты продукт-плейсмента в фильмах был проведён качественный контент-анализ научной литературы. Принимая во внимание недостаток исследований литовских авторов, в статье анализируются публикации зарубежных авторов (Sargent et al., 2001; Jin, Villegas, 2007; Sung et al., 2008; Wiles, Danielova, 2009 и др.). В статье анализируются различные подходы к демонстрированию продуктов в художественных фильмах, предоставляемые различными авторами, обобщаются различные концепции демонстрирования продуктов в художественных фильмах, определяются потенциальные области применения такой деятельности. Для теоретических исследований применяются генеральные научно-исследовательские методы логического анализа и синтеза научной литературы.

Результаты. Продукт-плейсмент в художественных фильмах можно назвать альтернативным способом для достижения целевой аудитории и выявление преимуществ продукта. Демонстрирование продукта - это включение продукта или его идентификатора в контекст фильма с помощью звуковых или визуальных элементов. Основной целью демонстрирования продукта является повышение осведомленности клиентов, оказание положительного влияния на их предпочтение и намерение купить. 
Основным преимуществом продукт-плейсмента в художественных фильмах являются естественность, высокая концентрация внимания зрителя, неизбежность и раскрывание характера, создание положительных ассоциаций, стимулирование сбыта, и охват целевой аудитории.

Выводы. Научные исследования и реальная практика иностранных организаций показали, что продукт-плейсмент в художественных фильмах увеличивает осведомленность о товаре и делает положительное влияние на бренд и прямое влияние - на рост продаж. Дальнейшие исследования демонстрирования продукта в художественных фильмах следует проводить для определения корреляции между категорией продукта, жанром фильма и эффективностью демонстрации.

Ключевые слова: реклама, рекламные инструменты, стимулирование продаж. 